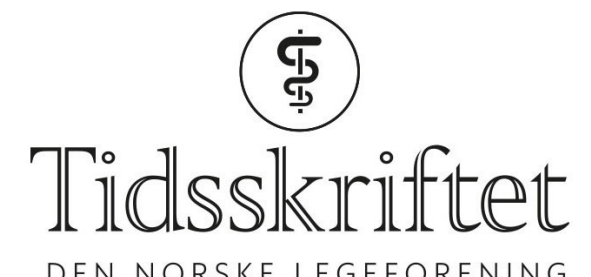

DEN NORSKE LEGEFORENING

\title{
Mangelfull behandling av slangebitt
}

FRA ANDRE TIDSSKRIFTER

\section{KRISTOFFER BRODWALL}

Barne- og ungdomsklinikken

Haukeland universitetssykehus

De fleste giftige slangeartene finnes i områder der det er dårlig tilgang til behandling av forgiftning.

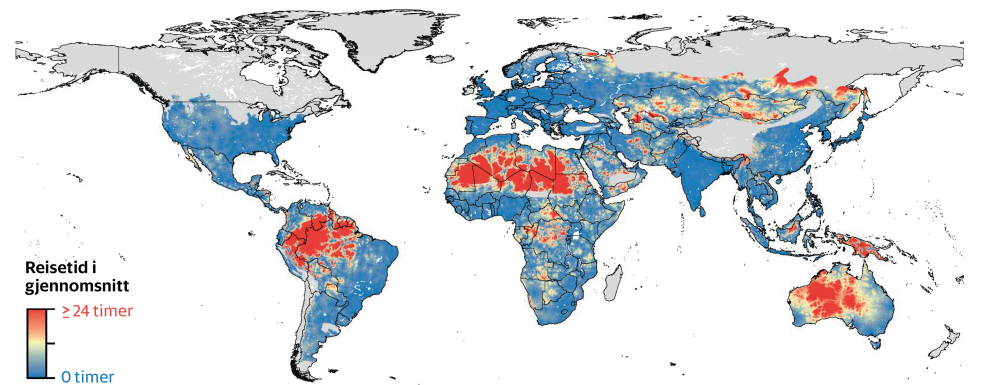

Gjennomsnittlig reisetid til ncermeste storby i områder med giftige slanger. De lysegrå områdene er uten farlige giftslangearter. Sudan, Algerie, Indonesia, Papua Ny-Guinea, Colombia og Peru er de spesielt utsatte områdene. Her kan tiden det tar å reise til et sted med motgift øke dødeligheten med mer enn 25 \%. Illustrasjon:Joshua Longbottom/The Lancet. Tilgjengelig under CC BY 4.o Lisens.

Slangebitt antas å være årsak til rundt 100 ooo dødsfall hvert år, og det totale antallet forgiftninger antas å være omkring ti ganger så høyt. Problemet er så stort at Verdens helseorganisasjon i 2017 inkluderte slangebitt på sin liste over neglisjerte tropiske sykdommer. En stor andel av alle slangebitt rammer folk på landsbygda i $ø$ øøst-Asia og Afrika sør for Sahara. Risikoen for forgiftning fra slangebitt er lite omtalt i forskningslitteraturen, men i en fersk oversiktsartikkel har forfatterne samlet dagens kunnskap om helsetrusselen som verdens giftige slanger utgjør (1).

Alt i alt er det beskrevet 278 giftige slangearter, men spesifikk antidot finnes mot bare litt over halvparten av dem. De 119 artene man ikke har antidot mot, finnes hovedsakelig i VestAfrika, Sentral-Afrika, Sør-Amerika og Sør-Asia. Uansett, men særlig når antidot ikke er tilgjengelig, er organstøttende sykehusbehandling viktig for overlevelse.

Anslagsvis 6,85 milliarder mennesker, dvs. over 9o \% av verdens befolkning, bor i et område der det finnes giftige slanger. Omkring en tidel av disse har over én times reiseavstand til nærmeste by. Reiseavstanden til nærmeste storby er særlig lang i mange av områdene der giftige slanger er særlig utbredt, som vist på illustrasjonen. Dette innebærer at mange av menneskene med den høyeste risikoen for å bli bitt av giftige slanger også er blant de som har dårligst tilgang på adekvat behandling. 
LITTERATUR:

1. Longbottom J, Shearer FM, Devine M et al. Vulnerability to snakebite envenoming: a global mapping of hotspots. Lancet 2018;392: 673-84. [PubMed][CrossRef]

Publisert:30. oktober 2018. Tidsskr Nor Legeforen. DOI: 10.4045/tidsskr.18.0694

(C) Tidsskrift for Den norske legeforening 2020. Lastet ned fra tidsskriftet.no 